\title{
Efficient Production of an Engineered Apoptin from Chicken Anemia Virus in a Recombinant $E$. coli for Tumor Therapeutic Applications
}

Meng-Shiou Lee ${ }^{1}$, Fang-Chun Sun ${ }^{2}$, Chi-Hung Huang ${ }^{3}$, Yi-Yang Lien ${ }^{4}$, Shin-Huei Feng ${ }^{5}$, Guan-Hua Lai ${ }^{5}$, Meng-Shiunn Lee ${ }^{6}$, Jung Chao ${ }^{7}$, Hsi-Jien Chen ${ }^{8}$, Jason T C. Tzen ${ }^{5 *}$ and Hao-Yuan Cheng ${ }^{9^{*}}$

\begin{abstract}
Background: Apoptin, a nonstructural protein encoded by the VP3 gene of chicken anemia virus (CAV), has been shown to not only induce apoptosis when introduced into the precursors of chicken thymocytes, but has been found to specifically kill human cancer cells, tumor cell and transformed cells without affecting the proliferation of normal cells. This tumor-specific apoptotic characteristic of the protein potentially may allow the development of a protein drug that has applications in tumor therapy. However, several major problems, which include poor expression and poor protein solubility, have hampered the production of apoptin in bacteria.

Results: Significantly increased expression of recombinant full-length apoptin that originated from chicken anemia virus was demonstrated using an E. coli expression system. The CAV VP3 gene was fused with a synthetic sequence containing a trans-acting activator of transcription (TAT) protein transduction domain (PTD). The resulting construct was cloned into various different expression vectors and these were then expressed in various E. coli strains. The expression of the TAT-Apoptin in E. coli was significantly increased when TAT-Apoptin was fused with GST-tag rather than a His-tag. When the various rare amino acid codons of apoptin were optimized, the expression level of the GST-TAT-Apoptin opt in E. coli BL21(DE3) was significantly further increased. The highest protein expression level obtained was $8.33 \mathrm{~g} / \mathrm{L}$ per liter of bacterial culture after induction with $0.1 \mathrm{mM}$ IPTG for $4 \mathrm{~h}$ at $25^{\circ} \mathrm{C}$. Moreover,

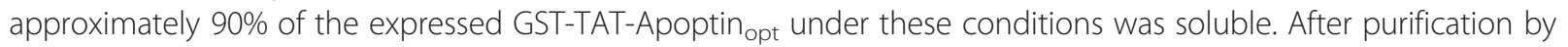
GST affinity chromatography, the purified recombinant TAT-Apoptin ${ }_{\text {opt }}$ protein was used to evaluate the recombinant protein's apoptotic activity on tumor cells. The results demonstrated that the E. coli-expressed GSTTAT-apoptin ${ }_{\text {opt }}$ showed apoptotic activity and was able to induce human premyelocytic leukemia HL-60 cells to enter apoptosis.
\end{abstract}

Conclusions: On expression in E. coli, purified recombinant TAT-Apoptin ${ }_{\text {opt }}$ that has been fused to a GST tag and had its codons optimized, was found to have great potential. This protein may in the future allow the development of a therapeutic protein that is able to specifically kill tumor cells.

\footnotetext{
*Correspondence: TCTZEN@dragon.nchu.edu.tw; m098026@cjc.edu.tw

${ }^{5}$ Graduate Institute of Biotechnology, College of Agriculture and Natural

Resources, National Chung Hsing University, Taichung, Taiwan

${ }^{9}$ Department of Nursing, Chung Jen College of Nursing, Health Sciences and

Management, Chia-Yi, Taiwan

Full list of author information is available at the end of the article
} 


\section{Background}

Chicken anemia virus (CAV), is a non-enveloped virus and the causative agent of chicken anemia disease. The disease results in aplastic anemia, lymph organ atrophy and immunosuppression in chickens [1-3]. The virus transcribes and translates three viral proteins, VP1, VP2 and VP3, which are respectively encoded by ORF3, ORF1 and ORF2 of the CAV genome. VP1 protein $(51 \mathrm{kDa})$ is the sole structural protein of CAV and is responsible for capsid assembly [4]. The VP2 protein $(30 \mathrm{kDa})$ is a nonstructural protein that possesses a dual-specificity protein phosphatase (DSP) [5]. The VP3 protein $(13 \mathrm{kDa})$, also called apoptin, is a strong inducer of apoptosis in precursor chicken thymocytes and various human transformed and tumor cell lines but not in normal cells [6]. At present, the full anti-tumor mechanism of apoptin remains unclear. However, it is worth mentioning that apoptin-induced apoptosis in tumor cells is p53-independent and also is not suppressed by Bcl-2 or BCR-ABL protein [7]. Thus, apoptin is thought to be a good candidate for use as a therapeutic protein and has potential to be developed as a cancer treatment, including those cancers that lack p53.

To develop apoptin as an anti-cancer drug, efficient transduction tools such as recombinant virus and a recombinant plasmid within liposomes have been used to deliver apoptin into tumor cells [8]. However, these approaches have restrictions in terms of therapeutic application including a size limitation of the genes that can be delivered, insertional mutagenesis and transient expression [9-11]. Novel cell-penetrating peptides, such as the trans-acting activator of transcription (TAT) protein transduction domain (PTD), which consists of 11 amino acid residues (aa 47-57, YGRKKRRQRRR) have therefore been used as vectors for protein delivery $[8,12]$. With respect to apoptin, previously studies have been demonstrated that apoptin fused with a TAT peptide shows apoptotic activity against tumor cells because the TAT peptide's delivery system is able to move apoptin into cells $[13,14]$.

Up to the present, a number of different expression systems have been used to express apoptin, including $E$. coli, baculovirus-insect cells and plant cells [15-18]. However, production of recombinant full-length apoptin/VP3 protein has generally been possible only in $E$. coli [17]. Several production problems involving the expression efficiency and protein solubility of apoptin in $E$. coli have been encountered $[13,17,18]$. Thus, there is a need to overcome these difficulties in order to scale-up production of full-length apoptin protein using an E. coli expression system. If successful, this would not only allow the efficient development of a therapeutic protein that is able to actively kill cancer cells specifically but the recombinant protein would also be potentially useful when developing diagnostic kits for the clinical detection of CAV infection [17].

It is clear that $E$. coli has a number of limitations and disadvantages in terms of the production of apoptin protein. However, expression of apoptin protein in E. coli is still an attractive alternative to the current production system when assessed in terms of cost, time and operational considerations. In this study, the CAV VP3 gene was fused to a synthetic gene containing the trans-acting activator of transcription (TAT) protein transduction domain (PTD). This protein, named TAT-Apoptin, was expressed using various different expression vectors in order to evaluate TAT-Apoptin expression and production by a number of different $E$. coli strains. Two expression vectors were used, one harboring a glutathione-Stransferase (GST) tag and the other a 6xHis tag; these were investigated to explore the effect of these fusion tags on the expression of TAT-Apoptin in the various $E$. coli strains. In addition, changes in codon usage for various amino acids within the VP3 gene were also assessed in terms of their effect on expression of TAT-Apoptin ${ }_{\text {opt }}$. Rare codons for E. coli within the VP3 gene of the TATApoptin protein were optimized using prediction software and the preferred codon usage changed to that of $E$. coli. After this optimization, the expression levels of the modified VP3 genes were examined in various $E$. coli strains and the various production parameters for TATApoptin $_{\text {opt }}$ protein expression assessed. To the best of our knowledge, the yield of $E$. coli expressed recombinant TAT-Apoptin ${ }_{\text {opt }}$ in this study after codon optimization of the VP3 gene is the highest known to date.

\section{Results}

A GST fusion tag improves the expression of recombinant TAT-Apoptin protein in E. coli

To develop apoptin protein as anti-tumor drug, a composite cDNA of the CAV VP3 gene fused synthetic gene of TAT peptide was used to create two distinct expression constructs of TAT-Apoptin (Figure 1A, a and b). These constructs, pET-TAT-VP3 and pGEX-TAT-VP3, were transformed into three different $E$. coli strains in order to investigate the effect of the fusion tags on the expression of TAT-Apoptin. The $6 \times$ His and GST tags were fused with TAT-Apoptin at the N-terminus using the expression vectors pET28a and pGEX-4 T-1, respectively. The expression of these two TAT-Apoptin constructs in various $E$. coli strains was explored (Figure 2). When E. coli BL21(DE3) was used, significant amounts of full-length TAT-Apoptin protein were present in the whole cell lysate after IPTG induction for $4 \mathrm{~h}$ with either pET-TAT-VP3 or pGEX-TAT-VP3 (Figure 2B, SDSPAGE and Western-blotting). The $16 \mathrm{kDa}$ His-TATApoptin and the $42 \mathrm{kDa}$ GST-TAT-Apoptin were detected using monoclonal anti-His antibody and anti- 


A
A the

GST antibody, respectively (Figure 2B, lane 4 of Western-blot). Densitometric analysis of the blots showed that total expressed GST-TAT-Apoptin protein, both soluble and insoluble, from BL21(DE3) was approximately 19 fold greater than that of His-TAT-Apoptin produced under identical conditions (Figure $3 \mathrm{~A}$ and $\mathrm{C}$ ). When His-TAT-Apoptin and GST-TAT-Apoptin were induced for between 1 and $4 \mathrm{~h}$, the expression of both proteins continued to increase significantly over the $2-4 \mathrm{~h}$ induction range (Figure $3 \mathrm{~A}$ and $\mathrm{C}$ ) with the highest amount of His-TAT-Apoptin protein produced being $0.34 \mathrm{mg} / \mathrm{ml}$ at $4 \mathrm{~h}$ of IPTG induction. In contrast, the highest amount of GST-TAT-Apoptin produced was $7.13 \mathrm{mg} / \mathrm{ml}$ at $4 \mathrm{~h}$. A similar pattern of expression was observed for the two proteins in BL21(DE3)CodonPlus-RP and BL21(DE3) pLysS strains (Figure 2). The highest amounts of GSTTAT-Apoptin produced by BL21(DE3)CodonPlus-RP and by BL21(DE3)pLysS were 2.43 and $1.15 \mathrm{mg} / \mathrm{ml}$, respectively, after $4 \mathrm{~h}$ of IPTG induction (Figure $3 \mathrm{~A}$ and C). The parallel results for His-TAT-Apoptin were 0.09 and $0.82 \mathrm{mg} / \mathrm{ml}$, respectively (Figure 3A and C). Thus the GST fusion tag improved protein expression significantly and allowed large amounts of intact TAT-Apoptin protein to be produced.

\section{VP3 gene encoding apoptin protein of CAV is rich in $E$. coli rare codons}

CAV VP3 gene that encodes the apoptin protein consists of 121 amino acid codons. The rare codons for E. coli within the VP3 gene were pinpointed using the GenScript Rare Codon Analysis Tool (http://www.genscript. com/cgi-bin/tools/rare_codon_analysis). The deduced amino acid sequence of apoptin was found to contain $15 \%$ basic amino acid residues such as arginine $(\mathrm{R})$ and lysine (K) (Figure 1B). Overall, approximately 21\% rare E. coli codons were present in the VP3 gene, including arginine, leucine, isoleucine, proline, cysteine, threonine, serine and glycine codons (Figure 1B). The presence of these codons is one possible reason for the relatively poor expression of apoptin in E. coli.

\section{Enhancement of recombinant TAT-Apoptin protein expression in $E$. coli by optimizing the codon usage of the VP3 gene}

We have shown that expression of full-length TATApoptin in E. coli is improved by fusing a GST tag to the $\mathrm{N}$-terminus of the TAT-Apoptin protein. However, adding a His tag to give His-TAT-Apoptin did not produce such a yield improvement even when the optimal host strain BL21(DE3)pLysS is used (Figures $2 \mathrm{~A}$ and 3A). Therefore, we next explored the effect on TATApoptin productivity of optimizing the codon usage of the VP3 gene for E. coli. The TAT-Apoptin gene was engineered such that AGA/CGA/CGG were changed to CGT or CGC (R), CCC/CCT were changed to CCG or CCA (P), CTC/CTA/TTG were changed to CTG (L), ATA was changed to ATC (I), GGA/GGG were changed to GGT (G), ACT/ACA were changed to ACC (T), 


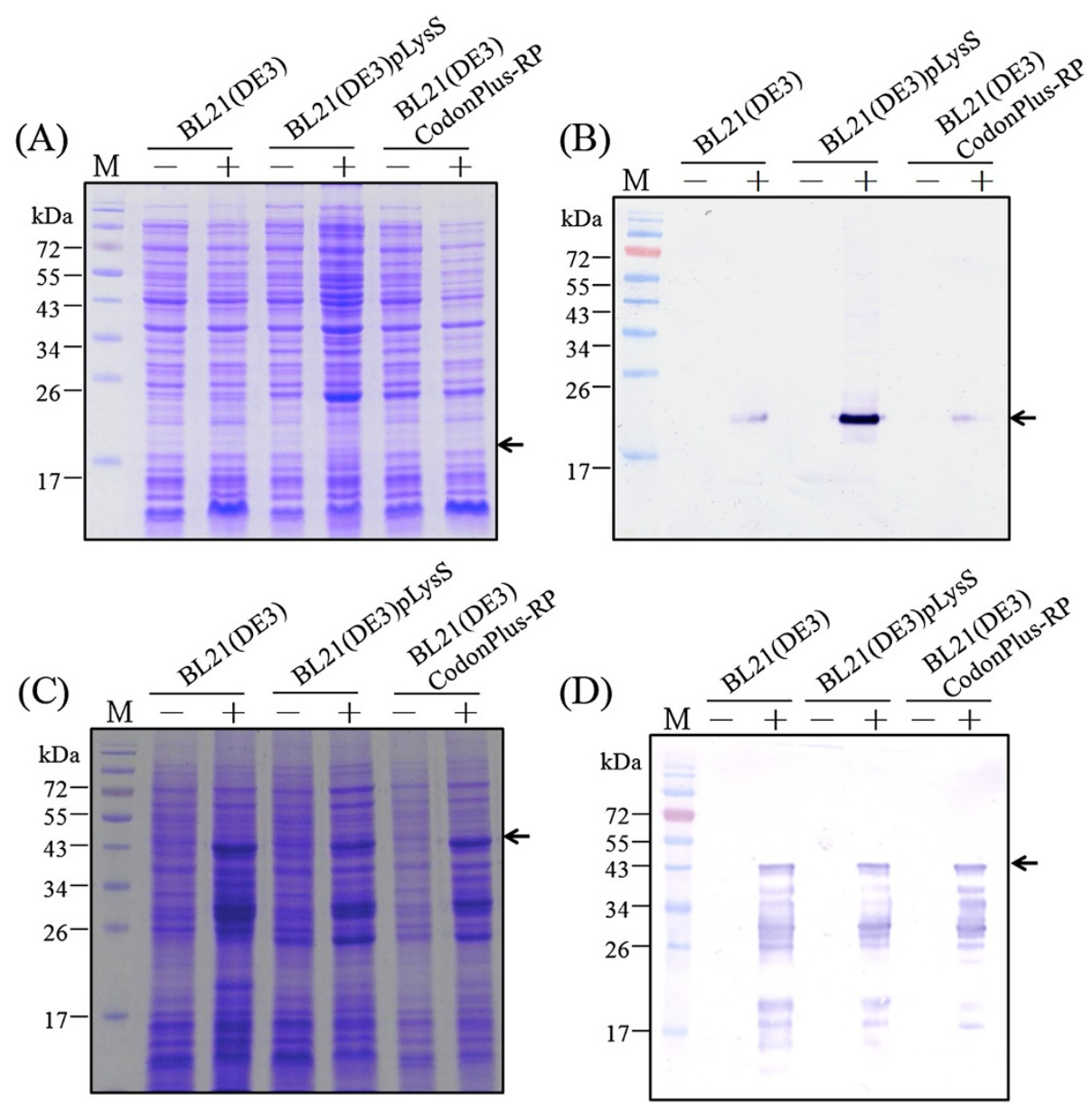

Figure 2 Expression of recombinant TAT-Apoptin protein in three different $E$. coli strains. The TAT-Apoptin protein expression in three $E$. coli strains, BL21(DE3), BL21(DE3)pLysS and BL21(DE3)CodonPlus-RP, which were transformed with either pET-TAT-VP3 or pGEX-TAT-VP3 and cultivated at $37{ }^{\circ} \mathrm{C}$. His-TAT-Apoptin and GST-TAT-Apoptin protein were examined and detected using SDS-PAGE (A, C) and Western-blotting (B, D). Anti-His and anti-GST tag monoclonal antibodies was respectively used to recognize the His-TAT-Apoptin protein and GST-TAT-Apoptin. Lane M, pre-stained protein marker; the symbols "-" and " + " represented pre-induction and post-induction with 1 mM of IPTG over 4 hrs of cultivation in E. coli, respectively.

and CAA was changed to CAG (Q) (Figure 1B). The codon optimized VP3 gene was then linked to the TAT sequence at 5 ' end of the VP3 gene to give an intact open reading frame. The new codon-optimized TATVP3 gene, denoted TAT-VP3 ${ }_{\text {opt }}$, was then cloned into pGEX-4 T-1 and pET28a to give pGEX-TAT-VP3 $3_{\text {opt }}$ and pET-TAT-VP3 $3_{\text {opt }}$, respectively (Figure $1 \mathrm{~A}, \mathrm{~d}$ and $\mathrm{c}$ ). These plasmids were then individually expressed in $E$. coli. When expression in E. coli strain BL21(DE3) using whole cell lysate was analyzed by SDS-PAGE and Western blotting, both GST-TAT-Apoptin ${ }_{\text {opt }}$ and HisTAT-Apoptin ${ }_{\text {opt }}$ were successfully expressed after IPTG induction (Figure $4 \mathrm{~A}$ and $\mathrm{C}$ ) with a yield after $4 \mathrm{~h}$ IPTG induction of about $9 \mathrm{mg} / \mathrm{ml}$ and $0.65 \mathrm{mg} / \mathrm{ml}$, respectively. The yield of GST-TAT-Apoptin ${ }_{\text {opt }}$ was almost 13 fold higher than His-TAT-Apoptin ${ }_{\text {opt }}$ $(0.65 \mathrm{mg} / \mathrm{ml}$ ) (Figure 5A and C). BL21(DE3)-pLysS, similarly, gave increased expression of both His- TATApoptin $_{\text {opt }}$ and GST-TAT-Apoptin ${ }_{\text {opt }}$ (Figure 4A and C). The highest yields of GST-TAT-Apoptin ${ }_{\text {opt }}$ and HisTAT-Apoptin ${ }_{\text {opt }}$ in BL21(DE3)pLysS were obtained after $4 \mathrm{~h}$ IPTG induction and were 6.38 and $1.2 \mathrm{mg} / \mathrm{ml}$, respectively (Figure 5A and C). These results confirm that the codon-optimized of TAT-Apoptin improved protein expression significantly and allowed large amounts of intact TAT-Apoptin ${ }_{\text {opt }}$ protein to be produced in either E. coli BL21(DE3) or BL21(DE3)pLysS with either fusion tag.

Effect of cultivation temperature and IPTG concentration on the protein solubility of E. coli-expressed GST-TAT-

\section{Apoptin $_{\text {opt }}$}

In addition to the expression level of TAT-Apoptin ${ }_{\mathrm{opt}}$, the solubility of TAT-Apoptin ${ }_{\text {opt }}$ protein is also needs to 


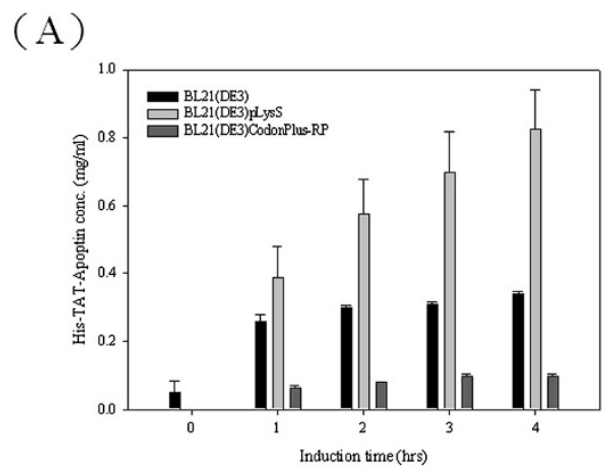

(C)

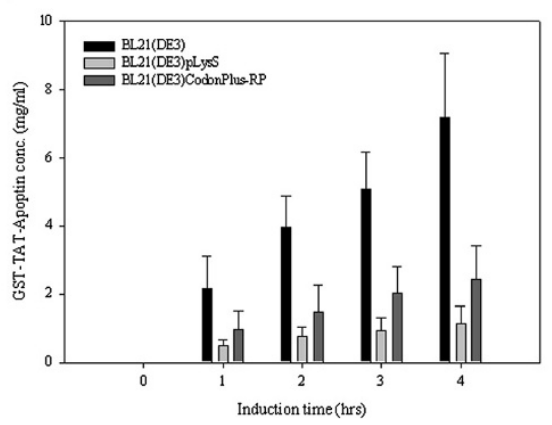

(B)

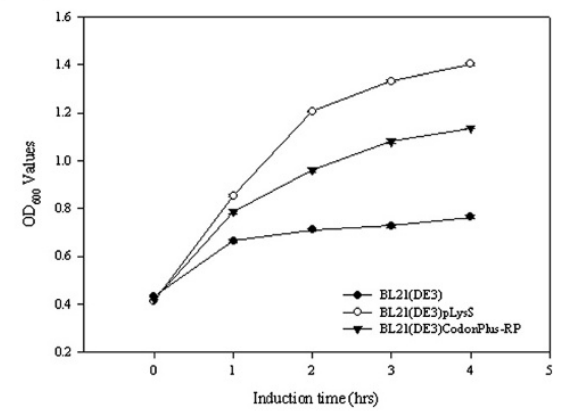

(D)

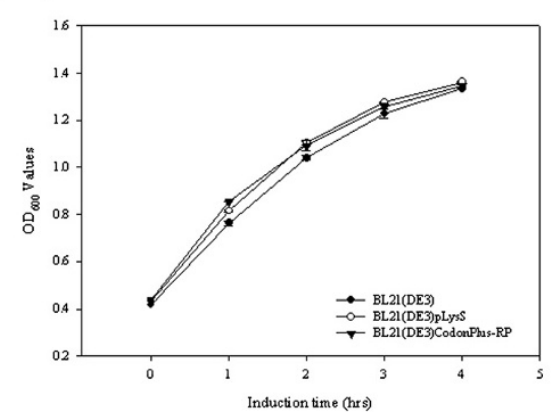

Figure 3 Productivities of TAT-Apoptin protein and the growth curves of the three recombinant $E$. coli strains. The productivities of HisTAT-Apoptin (A) and GST-TAT-Apoptin (C) for the three E. coli strains, BL21(DE3), BL21(DE3)pLysS, and BL21(DE3)CodonPlus-RP containing pETTAT-VP3 or PGEX-TAT-VP3 are shown over the time course of cultivation at $37{ }^{\circ} \mathrm{C}$ after IPTG induction. The growth curves of BL21(DE3), BL21(DE3) CodonPlus-RP and BL21(DE3)pLysS expressing His-TAT-Apoptin (B) and GST-TAT-Apoptin (D), respectively, in LB medium post-induction.

examine and improved. To this end, the cultivation parameters and their effect on the TAT-Apoptin ${ }_{\text {opt }}$ protein solubility were explored, namely cultivation temperature and the IPTG concentration for induction; GST-TAT-Apoptin opt $_{\text {was }}$ used as the model protein. Protein solubility and the expression levels of GST-TATApoptin $_{\text {opt }}$ were determined using E. coli BL21 (DE3) at $25^{\circ} \mathrm{C}$ and $37{ }^{\circ} \mathrm{C}$. As shown in Figure $6 \mathrm{~A}$, an increased amount of soluble GST-TAT-Apoptin ${ }_{\text {opt }}$ was obtained after IPTG induction at $25{ }^{\circ} \mathrm{C}$. Approximately $15 \%$ and $65 \%$ of the GST-TAT-Apoptin ${ }_{\text {opt }}$ in the whole cell lysate of the BL21(DE3) strain was soluble at $37{ }^{\circ} \mathrm{C}$ and $25{ }^{\circ} \mathrm{C}$, respectively. In addition, the amounts of GST-TATApoptin $_{\text {opt }}$ protein expressed in BL21(DE3) were $8.33 \mathrm{mg} / \mathrm{ml}$ and $8.99 \mathrm{mg} / \mathrm{ml}$, respectively, at $25^{\circ} \mathrm{C}$ and $37{ }^{\circ} \mathrm{C}$ after $4 \mathrm{~h}$ IPTG induction (Figures $5 \mathrm{C}$ and $7 \mathrm{~A}$ ); thus the total amount of GST-TAT-Apoptin ${ }_{\text {opt }}$ protein obtained at $25{ }^{\circ} \mathrm{C}$ compared to $37{ }^{\circ} \mathrm{C}$ was only very slightly lower (Figures 5C and 7A).

When various IPTG induction concentration from 0.1 to $1 \mathrm{mM}$ were explored for protein induction, the highest amount of GST-TAT-Apoptin ${ }_{\text {opt }}$ protein obtained was with $1 \mathrm{mM}$ IPTG induction using the BL21(DE3) strain (Figure 6B) and this gave about 65\% soluble protein at $25{ }^{\circ} \mathrm{C}$ (Figure 6C). The expression level of GST-
TAT-Apoptin $_{\text {opt }}$ at 0.1 and $0.5 \mathrm{mM} \mathrm{IPTG}$ was lower than for $1 \mathrm{mM}$ IPTG (Figure 6B), but the amount of soluble protein was highest at $0.1 \mathrm{mM}$ (95\%) IPTG (Figure 6C). Thus a lower cultivation temperature of $25{ }^{\circ} \mathrm{C}$ and an IPTG concentration of $0.1 \mathrm{mM}$ IPTG were able to produce the higher amount of soluble GST-TAT-Apoptin ${ }_{\mathrm{opt}}$ protein.

\section{Purification of recombinant GST-TAT-Apoptin ${ }_{\text {opt }}$ protein using GST affinity chromatography}

Using the approximately $95 \%$ soluble GST-TAT-Apopti$\mathrm{n}_{\text {opt }}$ expressed by E. coli at $25^{\circ} \mathrm{C}$ and $0.1 \mathrm{mM}$ IPTG, the lysate was subjected to purification using a GST affinity column. After affinity chromatography, the eluted soluble GST-TAT-Apoptin ${ }_{\text {opt }}$ protein was confirmed antigenically using anti-GST antibody and CAV-infected positive serum (Figure $8 \mathrm{~A}, \mathrm{~B}$ and $\mathrm{C}$ ). A typical elution profile of the protein fractions collected from a GST column is shown in Figure 8A after separation by SDSPAGE. Fraction 4 contains the most eluted protein, has a significant absorbent peak at $\mathrm{OD}_{280}$ and was eluted at $12 \mathrm{~min}$ (data not shown). The specific $42 \mathrm{kDa}$ band eluted in fraction 4 was almost purified to homogenicity (Figure 8A, lane 4 of elution). When the purified GSTTAT-Apoptin ${ }_{\text {opt }}$ protein was examined by MALDI-TOF, 

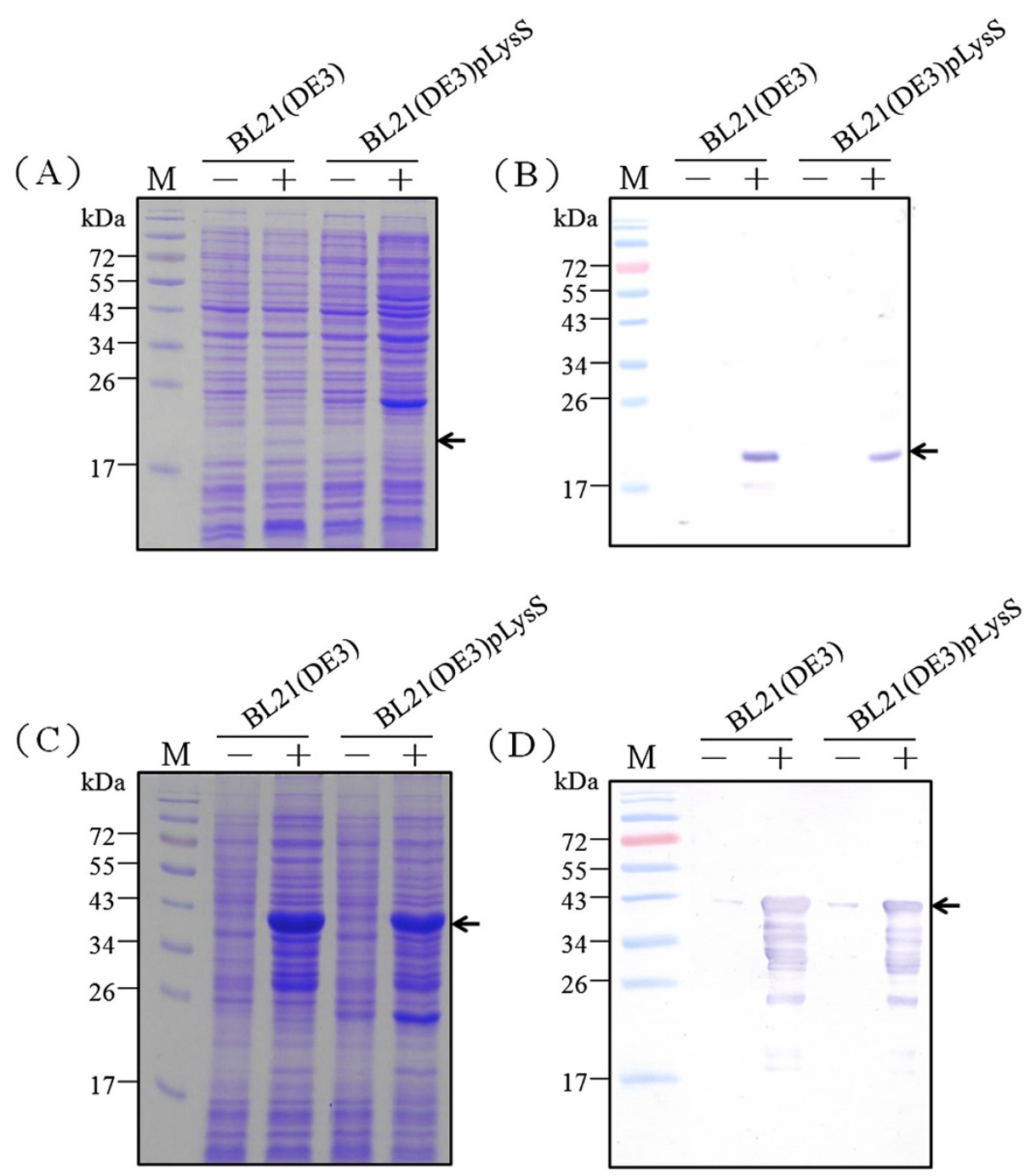

Figure 4 Expression of recombinant TAT-Apoptin ${ }_{\text {opt }}$ protein in the different $E$. coli strains. The TAT-Apoptin ${ }_{\text {opt }}$ protein was expressed in the E. coli strains BL21(DE3) and BL21(DE3)pLysS, which contained either pET-TAT-VP3 opt or pGEX-TAT-VP3 ${ }_{\text {opt }}$ at $37^{\circ}{ }^{\circ}$. His-TAT-Apoptin opt and GST-TAT-Apoptin $_{\text {opt }}$ protein were examined and detected using SDS-PAGE (A, C) and Western-blotting (B, D). Anti-His and anti-GST tag

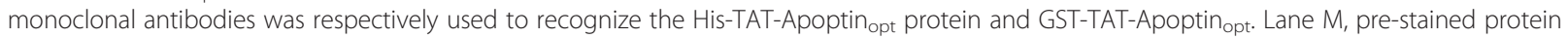
marker; "-" and "+" represented pre-induction and post-induction with 1 mM of IPTG over 4 hrs of cultivation in E. coli, respectively.

seven peptides from GST-TAT-Apoptin ${ }_{\text {opt }}$ could be identified after trypsin digestion and these demonstrated good alignment and a high score when compared to the predicted protein (data not shown). The longest peptide fragment, VNELKESLITTTPSRPR, consists of 17 amino acid residues and overall the coverage was $35.7 \%$ of the published amino acid sequence of apoptin (Accession No. AF212490) without any miss-match (Figure 8D). These MALDI-TOF results confirmed that the purified $42 \mathrm{kDa}$ protein is GST-TAT-Apoptin ${ }_{\text {opt }}$ and that the $E$. coli preferred codon usage optimization within the VP3 gene has not altered either the amino acid sequence (Figure 8C; Figure 8B, lane 4) or the antigenicity (Figure $8 \mathrm{C}$ ) of the protein.

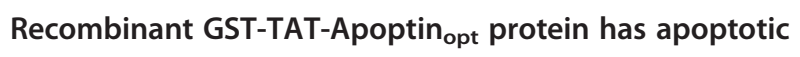
activity and induces apoptosis in $\mathrm{HL}-60$

To investigate whether GST-TAT-Apoptin ${ }_{\mathrm{opt}}$ protein expressed by $E$. coli has apoptotic activity when introduced into tumor cells, purified GST-TAT-Apoptin ${ }_{\mathrm{opt}}$ protein was used to examine the protein's apoptotic activity when it was used to treat human premyelocytic leukemia HL-60 cells. As illustrated in Figure 9, flow cytometry analysis by Annexin-V FITC and propidium iodide staining showed an approximately $10 \%$ increase in the level of apoptotic levels among HL-60 cells that were co-cultured with GST-TAT-Apoptin ${ }_{\text {opt }}$ compared to HL-60 cells only, HL-60 co-cultured with GST or chromatographic elution buffer. However, compared to 


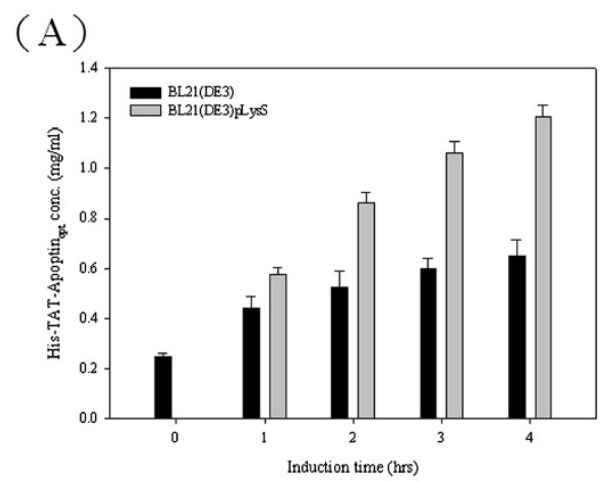

(C)

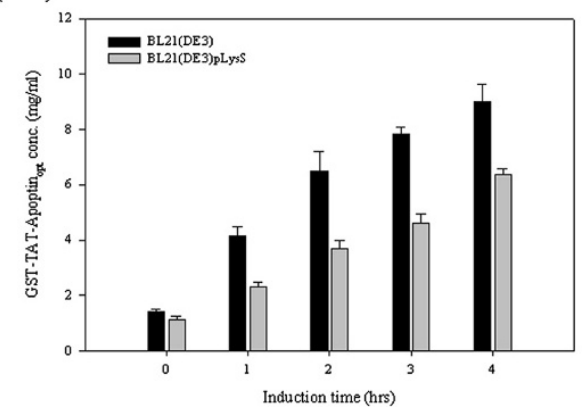

(B)

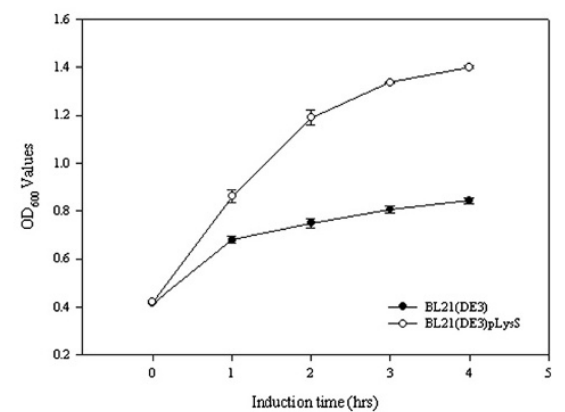

(D)

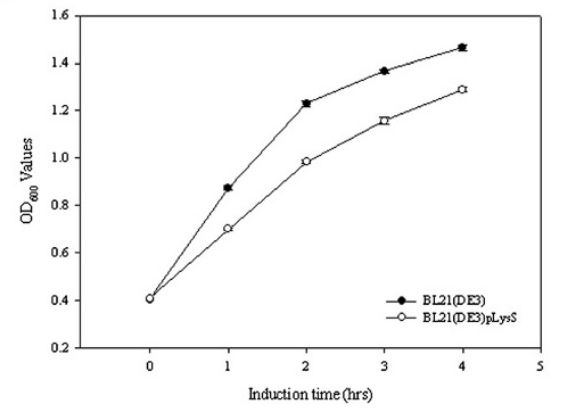

Figure 5 Productivities of TAT-Apoptin ${ }_{\text {opt }}$ protein and the growth curves of two recombinant $E$. coli strains. The productivities of His-TAT-

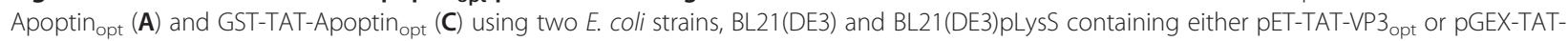
$\mathrm{VP3}_{\text {opt, }}$ respectively, are shown over a time course after IPTG induction at $37^{\circ} \mathrm{C}$. The growth curves of BL21(DE3) and BL21(DE3)pLysS expressing His-TAT-Apoptin $_{\mathrm{opt}}$ (B) and GST-TAT-Apoptin ${ }_{\mathrm{opt}}$ (D) in LB medium post-induction.

the control, HL-60 cells co-cultured with GST-TATApoptin $_{\text {opt }}$ induced less apoptosis than when HL-60 cells were induced into apoptosis by treatment with cyclohexamide (CHX). Nevertheless, GST-TAT-Apoptin ${ }_{\text {opt }}$ was able to induce apoptosis in HL-60 cells to a meaningful degree. These results indicate that E.coli expressed GSTTAT-Apoptin $_{\text {opt }}$ retains the protein's original apoptotic activity when used to treated HL-60 cells even after the modifications carried out in this study.

\section{Discussion}

Apoptin from chicken anemia virus has been demonstrated to have apoptotic activity and to be able to specifically kill several types of tumor cells including the cell lines HeLa, Saos-2, lung cancer cells H1299 and HepG2 $[9-11,13,14,19]$. Apoptin is not only p53 and $\mathrm{Bcl}^{-}$ independent, but also does not require specific postmodification in order to be able to induce apoptosis [7]. Therefore, apoptin has great potential to be developed into a protein drug that will be useful as part of the cancer therapy armory. In this context, previously studies have shown that fusing the TAT peptide to apoptin, in order to create a recombinant protein vehicle, which allows protein uptake by cells, improves protein translocation into the cell and increases Saos-2 cell killing
[19]. This approach is a useful was of overcoming problems associated with the delivery of apoptin into cells without affecting the anti-cancer activity of the protein. However, up to the present, few studies have investigated anti-cancer activity using such a recombinant TAT-Apoptin protein. The main reason for this lack of progress is the poor expression and low protein solubility of TAT-Apoptin. Previous studies have shown that the large-scale production of recombinant TAT-Apoptin using a prokaryotic expression is difficult and therefore this has become a bottle-neck [17,18]. Even today, in spite of the fact that many eukaryotic expression systems are well established, various factors, such as cost-effectiveness, insertional mutagenesis and transient expression, still need to be resolved for these systems. Taking the above into consideration, the effective production of TAT-Apoptin protein using a prokaryotic system is a crucial key step in developing this protein drug as an anti-tumor therapy. Therefore, in this study, the specific aim was to develop a prokaryotic expression system that allowed the efficient production of recombinant TATApoptin protein. Using a prokaryotic expression system to express heterologous recombinant protein has several advantages including time-savings, cost-effectiveness, ease of production, simplified characterization and 


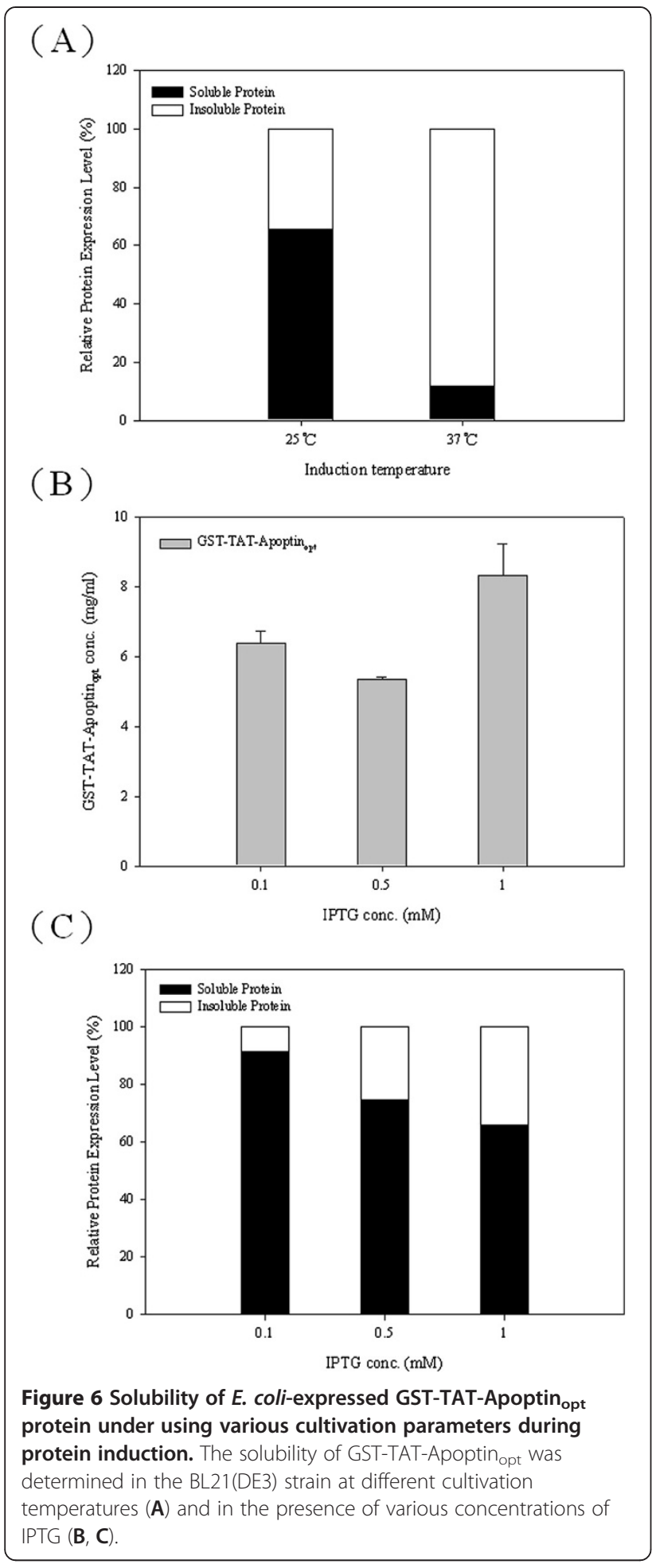

others. It is for these reasons that $E$. coli is the most used expression system when evaluating the expression of a foreign protein [20]. Indeed, the above points are some of the critical factors associated with choosing a suitable production system when developing a protein drug. To this end, problems associated with having a truly effective system for the large-scale production of apoptin protein still needed to be explored.

To improve protein expression and to enhance the solubility of any protein produced in an E. coli expression system, a number of strategies are available. These include cultivation parameters, the effect of fusing the protein to an affinity tag and the optimization of codon usage of foreign gene for E. coli. All of these have been frequently employed to improve the amount of recombinant protein recovered $[17,18,21-23]$. In the present study, we first explored the effect of two different fusion tags on TAT-Apoptin expression, although others remain available, are untested as yet and may further improve the yield in the future. The presence of a GST fusion tag was found to significantly improve the yield of TAT-Apoptin compared to a $6 \times$ His tag (Figures 2 and $3)$. In a previous study, Liu et al successfully overcame the problem of less efficient expression in $E$. coli of porcine circovirus (PCV) by fusing the maltose-binding protein (MBP) to an $8 x$ His tag [23]. The main mechanism by which the MBP-8xHis tag improved protein expression remains unclear. However, one possibility is improved protein solubility [24]. Similarly, in our previous study, the addition of a GST tag to the CAV VP1 protein also improved expression in $E$. coli significantly compared to a His $\times 6$ tag [21]. Thus it would seem that some fusion tags are able to improve expression of soluble protein in E. coli compared to other tags, perhaps by aiding the correct folding of their fused partner $[21,24]$.

Next we investigated which of three different $E$. coli strains, BL21(DE3), BL21(DE3)pLysS and BL21(DE3) Codonplus-RP, was able to improve protein production and yield. With both GST-TAT-Apoptin and His-TATApoptin, BL21(DE3) was preferred and produced more TAT-Apoptin protein than either BL21(DE3)pLysS or BL21(DE3)Codonplus-RP (Figure 2A and C). It is worth noting that BL21(DE3)pLysS has a higher growth rate than BL21(DE3) or BL21(DE3)Codonplus-RP when expressing His-TAT-Apoptin (Figure 2B and D). This discrepancy may involve either poor protein stability or the cytotoxic nature of His-TAT-Apoptin when present in BL21(DE3) and BL21(DE3)Codonplus-RP. These results are similar to those obtained for the production of GSTVP1 protein from CAV in E. coli at low expression levels [21]. BL21(DE3)pLysS superiority may be due to the presence in the strain of the $p L y s S$ plasmid during protein induction [17,21]. This difference may enable BL21(DE3) pLysS to tolerate cytotoxicity associated with the expression of T7 lysozyme by attenuating the transcription leakage by T7 RNA polymerase [17,21]. However, this phenomenon was not important when GST-TAT-Apoptin was expressed and the growth profiles of the three strains 

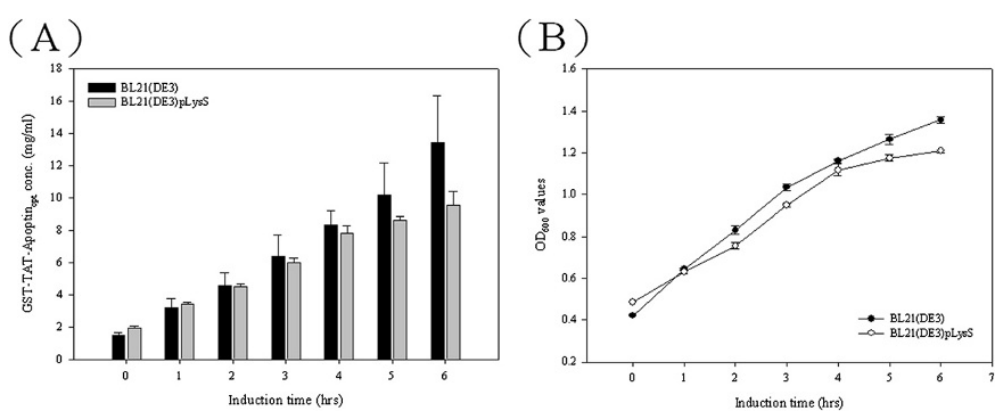

Figure 7 Productivities of TAT-Apoptin ${ }_{\text {opt }}$ protein and the growth curves in two recombinant E. coli strains. The productivities of GSTTAT-Apoptin $_{\text {opt }}$ using two E. coli strains, BL21(DE3) and BL21(DE3)pLysS containing PGEX-TAT-VP3 ${ }_{\text {opt }}$ are shown over time after IPTG induction at $25^{\circ} \mathrm{C}$ (A). Growth curves of BL21(DE3) and BL21(DE3)pLysS expressing GST-TAT-Apoptin opt, $_{\text {, }}$ respectively, in LB medium post-induction (B).

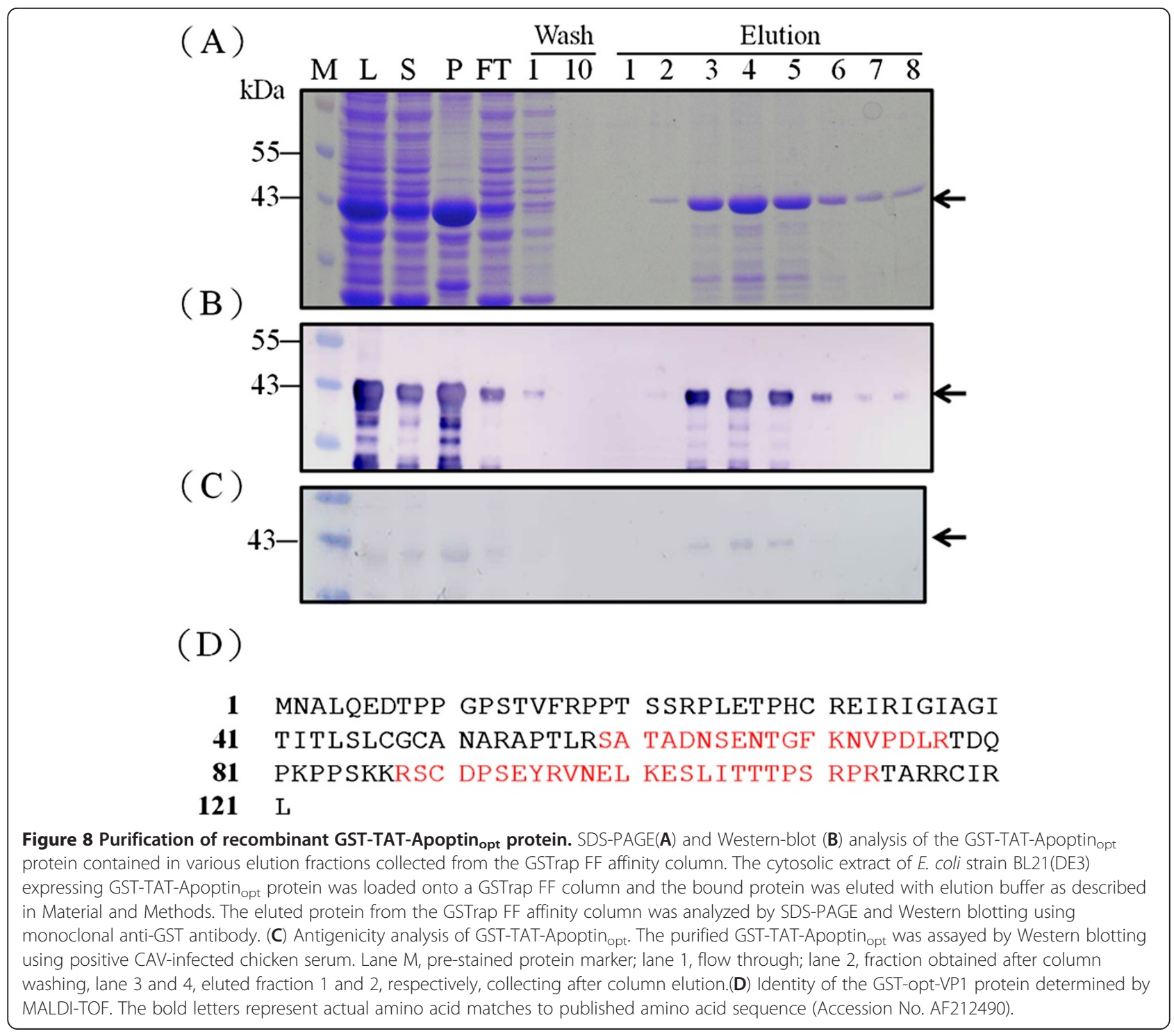


(A)

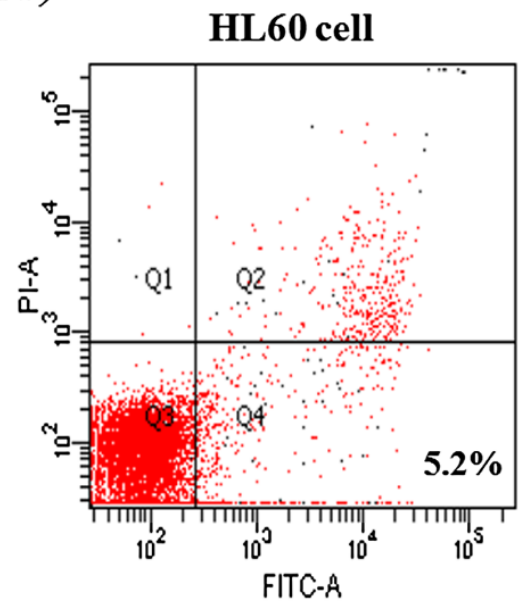

(C)

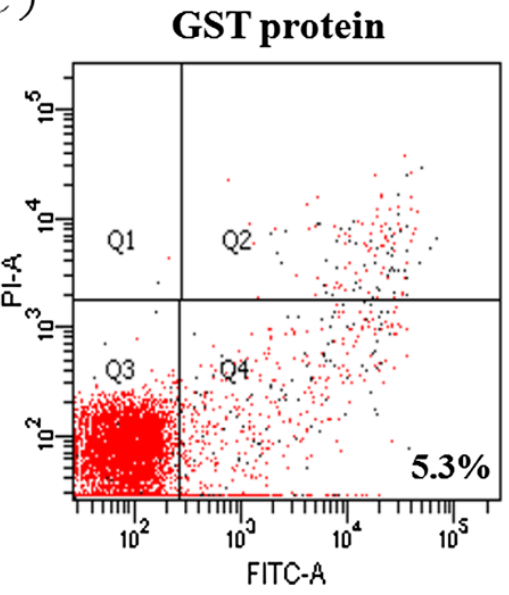

(E)

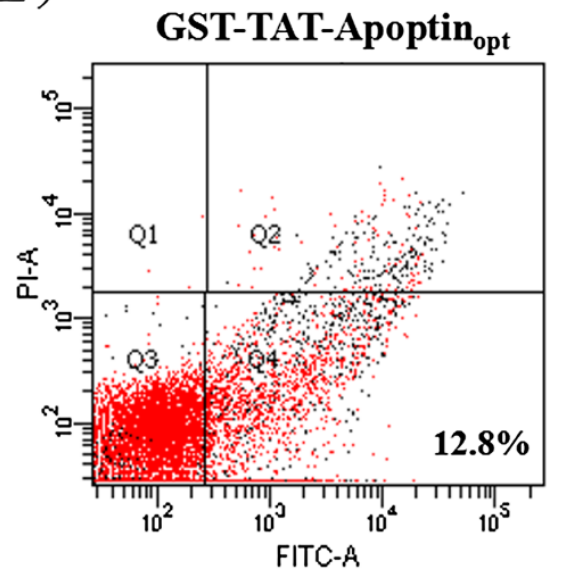

(B)

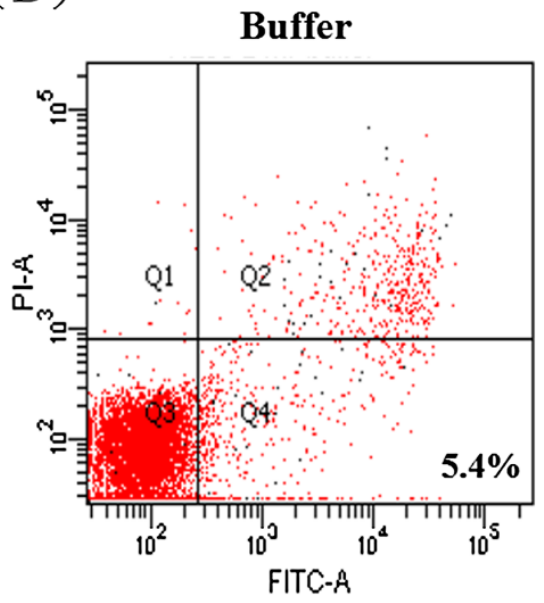

(D)

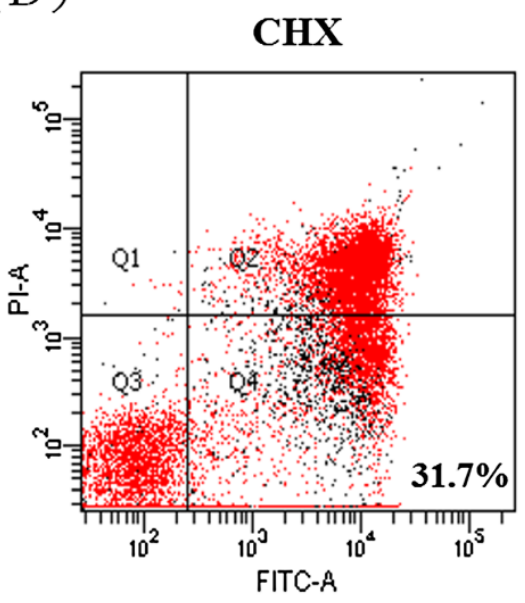


producing GST-TAT-Apoptin were almost identical on induction by IPTG. In this area, it is possible that the cytotoxicity of GST-TAT-Apoptin may be less that that of His-TAT-Apoptin in BL21(DE3) and BL21(DE3)Codonplus-RP [21]. Furthermore, the phenomenon of "protein burden" may not have been encountered when BL21(DE3) was used to express GST-TAT-Apoptin [25]. It was concluded that BL21(DE3) is the preferred choice for expression of GST-TAT-Apoptin.

Rosenberg et al have proposed that the abundance of a rare codon near the 5'-end of the gene might affect the efficiency of protein translation [26]. If this is true, then the approach used in the present study to modify the codon usage in the gene ought to improve the expression of full-length apoptin protein. When Genscript OptimumGene ${ }^{\mathrm{TM}}$ bioinformatic software was used to identify rare codons in $E$. coli that exist in the wild-type CAV VP3 gene, the pinpointed amino acid residues included arginine, leucine, proline and lysine; these are commonly found in the $\mathrm{N}$-terminus and C-terminus regions of the apoptin protein. After codon optimization of CAV VP3 gene, TAT-Apoptin opt $_{\text {was }}$ fused with both tags and successful expressed in E. coli (Figure 4A, C). The amount of expressed GST-TAT-Apoptin ${ }_{\text {opt }}$ in E. coli was substantially higher than that of GST-TAT-Apoptin and His-TAT-Apoptin ${ }_{\text {opt }}$ when BL21(DE3) or BL21(DE3) pLys were used (Figure 5A, C and Table 1). Thus codon optimization within VP3 gene of the rare codons in $E$. coli was able to improve the expression level of TATApoptin; specifically translation efficiency was improved without the need to supply extra copies of the rare tRNA genes [27,28]. Interestingly, in terms of growth, BL21 (DE3) and BL21(DE3)pLysS performed almost identically when expressing GST-TAT-Apoptin (Figure 3D). However, the growth rate of BL21(DE3)pLysS was significantly slower than that of BL21(DE3) when expressing GST-TAT-Apoptin $_{\text {opt }}$ (Figure 5D). This might be explained in terms of the "protein burden" within BL21 (DE3)pLysS when it is producing GST-TAT-Apoptin ${ }_{\mathrm{opt}}$ at a relatively high level early during induction and this protein burden may eventually result in BL21(DE3)pLys undergoing growth arrest. The growth profile of BL21
(DE3) expressing GST-TAT-Apoptin ${ }_{\text {opt }}$ may involve the balancing of the steady-state growth conditions for the strain with the yield and also suggests that this strain had reached the maximum possible growth rate; as a result the growth profile of BL21(DE3) during the expression of GST-TAT-Apoptin ${ }_{\text {opt }}$ did not significantly change (Table 1, Figures 3D and 5D). In contrast, when producing His-TAT-Apoptin ${ }_{\text {opt }}$, the growth profiles of BL21 (DE3) and BL21(DE3)pLysS were very similar to the situation when the strains were producing His-TATApoptin (Figures 3B and 5B). One possible explanation for this is that the level of produced His-TAT-Apoptin or His-TAT-Apoptin ${ }_{\text {opt }}$ did not reach the threshold value where there was a protein burden and therefore no growth arrest occurred.

The presence of a fusion tag and optimization of the codon usage within the gene were both useful strategies for improving the production of TAT-Apoptin (Table 1). When compared, the increase level in yield obtained when a fusion tag was used seems to be greater than that derived from codon optimization (Table 1). Specifically, the yield was only increased from $7.1 \mathrm{mg} / \mathrm{ml}$ (GSTTAT-Apoptin) to $8.9 \mathrm{mg} / \mathrm{ml}$ (GST-TAT-Apoptin opt $_{\text {) }}$ was expressed in BL21(DE3).

In order to improve the protein stability of TAT-Apoptin, various cultivation parameters were adjusted. Although a cultivation temperature of $37{ }^{\circ} \mathrm{C}$ was able to produce a higher growth rate and greater protein yield, this temperature did not produce a high yield of soluble protein. When $25^{\circ} \mathrm{C}$ was used or when a lower IPTG concentration was used ( $0.1 \mathrm{mM}$ of IPTG), it was not only possible to obtain a similar expression level of TAT-Apoptin within $6 \mathrm{hrs}$ (compared to $4 \mathrm{hrs}$ ), but there was also a significant improvement in protein solubility (Figures 6A, 7A). Recovering soluble TAT-Apoptin using the GST tag as an affinity ligand during the purification process is highly convenient in terms of downstream processing. After GST affinity chromatography, approximately $80 \%$ of the GST-TAT-Apoptin produced by the E. coli was recovered and recovery of GST-TATApoptin even reached over $90 \%$ with one batch (Figure 8). The purified target protein can then be

Table 1 Summary of the productivities of the various TAT-Apoptin proteins expressed in the range of $E$. coli strains

\begin{tabular}{|c|c|c|c|c|}
\hline \multirow[t]{2}{*}{ Protein } & \multicolumn{3}{|c|}{ Productivity of $E$. coli strains $(\mathrm{mg} / \mathrm{ml})$} & \multirow[t]{2}{*}{ Plasmid } \\
\hline & BL21(DE3) & pLysS & CodonPlus-RP & \\
\hline His-TAT-Apoptin & $0.34 \pm 0.01$ & $0.82 \pm 0.11$ & $0.09 \pm 0.01$ & pET-TAT-VP3 \\
\hline GST-TAT-Apoptin & $7.13 \pm 1.88$ & $1.15 \pm 0.49$ & $2.43 \pm 0.98$ & PGEX-TAT-VP3 \\
\hline His-TAT-Apoptin ${ }_{\text {opt }}$ & $0.65 \pm 0.06$ & $1.20 \pm 0.05$ & - & pET-TAT-VP3 ${ }_{\text {opt }}$ \\
\hline GST-TAT-Apoptin apt & $8.99 \pm 0.65$ & $6.38 \pm 0.18$ & - & pGEX-TAT-VP3 ${ }_{\text {opt }}$ \\
\hline GST-TAT-Apoptin bopt & $8.33 \pm 0.89$ & $7.84 \pm 0.44$ & - & pGEX-TAT-VP3 ${ }_{\text {opt }}$ \\
\hline
\end{tabular}

${ }^{\mathrm{a}} \mathrm{E}$. coli Strains were cultured at $37^{\circ} \mathrm{C}$.

${ }^{b} \mathrm{E}$. coli Strains were cultured at $25^{\circ} \mathrm{C}$. 
subjected to further purification steps in order to obtain a protein drug with high purity.

In this study, human premyelocytic leukemia HL-60 cells were used to evaluate the apoptotic activity of the E. coli-expressed TAT-Apoptin. Apoptosis was induced when the HL-60 cells were co-cultured with $90 \mathrm{ug} / \mathrm{ml}$ of GST column purified GST-TAT-Apoptin opt $_{\text {. There was a }}$ $10 \%$ increase in apoptosis compared to the non-apoptosis control (Figure 9A, B and C). However, this is less apoptosis than that induced by $\mathrm{CHX}$, which is the positive apoptosis control. Previous studies have reported that approximately $70 \%$ of tumor cells undergoing apoptosis in the presence of apoptin [11]. This discrepancy may be a result of differences in the tumor cell lines used, which may have different levels of tolerance with respect to apoptin. In addition, the TAT-Apoptin carried the GST fusion tag had not undergo protease cleavage before use and the presence of the tag may have affected the protein drug's apoptotic activity during co-culture with the tumor cells. Nevertheless, it is clear that the $E$. coli-expressed GST-TAT-Apoptin ${ }_{\text {opt }}$ produced in the present study does retain its anti-tumor cell activity and the ability to induce apoptosis.

\section{Conclusions}

The expression of recombinant full-length TAT-Apoptin protein was established successfully herein using a prokaryotic system, and the yield was significantly improved by fusing the protein with an affinity tag and by optimizing the codon usage of the polypeptide for expression in E. coli. Direct engineering of the apoptin protein was a convenient and cost-effective strategy of increasing the expression of TAT-Apoptin protein in E. coli. This paves the way for the large-scale production of TAT-Apoptin protein using this approach. In the future, this will also allow TAT-Apoptin to be used for the development of a protein drug that has anti-cancer activity or as part of a CAV diagnostic test.

\section{Methods}

\section{Bacterial strain and cells inoculation}

Three E. coli strains, BL21(DE3) (Invitrogen, Carlsbad, CA), BL21(DE3)CodonPlus-RP (Stratagene, La Jolla, CA) and BL21(DE3)pLysS (Stratagene, La Jolla, CA) were used and maintained at $37{ }^{\circ} \mathrm{C}$ using $10 \mathrm{ml}$ LuriaBertani (LB)medium (1\% tryptone, $0.5 \%$ yeast extract, $1 \% \mathrm{NaCl}, \mathrm{pH} 7.0)$ in $50 \mathrm{ml}$ flasks. For strain activation, $0.5 \mathrm{ml}$ of an overnight culture were inoculated into $50 \mathrm{ml} \mathrm{LB}$ medium and grown at $37{ }^{\circ} \mathrm{C}$ for around $3 \mathrm{~h}$, by which time the optical density of culture had reach 0.5 of $\mathrm{OD}_{600}$. These bacterial cells could then be used for transformation or for protein expression.

\section{Construction of the recombinant plasmids}

A $420 \mathrm{bp}$ of synthetic cDNA encoding the full-length CAV apoptin protein that was fused to a trans-acting activator of transcription (TAT) protein transduction domain (PTD) at its N-terminus, the latter being synthesized by Genemark Biosci \& Tech Co. (Taichung, Taiwan) and then ligated into pBluescript II SK(-) using Bam H1 (Takara, Japan) and Xho I (Takara, Japan) restriction sites. The resulting recombinant plasmid was designated pB-TAT-VP3. The TAT-VP3 gene then was subcloned into either pET28a (Novagen, Madison, WI) or pGEX-4 T-1 (GE Healthcare, Piscataway, NJ) using Bam $\mathrm{H} 1$ and Xho I. The resulting constructs were designated pET-TAT-VP3 and pGEX-TAT-VP3 (Figure 1A, a and b), respectively. To generate the VP3 gene of CAV harboring the codon optimized nucleotide sequence, a codon optimized fragment of VP3 gene fused with the TAT PDT was also synthesized by Genemark Biosci \& Tech Co. and then ligated into the pBluescript II SK(-) using Bam $\mathrm{H} 1$ and Xho I restriction sites. The TAT$V P 3_{\text {opt }}$ gene was then further subcloned into either pET28a or pGEX-4 T-1 as described above and the resulting constructs were designated pET-TAT-VP3 opt and pGEX-TAT-VP3 $3_{\mathrm{opt}}$, respectively (Figure $1 \mathrm{~A}, \mathrm{c}$ and d). The constructs described above were then transformed into One Shot ${ }^{\circledR}$ Top10 (Invitrogen, CA) chemically competent $E$. coli for maintenance of the recombinant plasmids and for protein expression. Transformants that contained a gene of the correct size by PCR were then confirmed as correct by restriction enzyme digestion and by DNA sequence analysis.

\section{Expression of TAT-Apoptin protein and codon optimized TAT-Apoptin $_{\text {opt }}$ protein in recombinant $E$. coli}

To express the His-TAT-Apoptin, GST-TAT-Apoptin, His-TAT-Apoptin opt $_{\text {and GST-TAT-Apoptin }}$ opt $_{\text {proteins, }}$ the four constructed recombinant plasmids, pET-TATVP3, pGEX-TAT-Apoptin, pET-TAT-VP3 ${ }_{\text {opt }}$ and pGEXTAT-VP $3_{\text {opt }}$, were transformed into $E$. coli strain to allow evaluation of protein expression. Three $E$. coli host strains, BL21(DE3), BL21(DE3)CodonPlus-RP and BL21 (DE3)pLysS, each being a different recombinant constructions, were used for protein induction and expression. The recombinant strains were grown in LB medium in the presence of kanamycin $(50 \mu \mathrm{g} / \mathrm{ml})$, ampicillin $(50 \mu \mathrm{g} / \mathrm{ml})$ or chloramphenicol $(34 \mu \mathrm{g} / \mathrm{ml})$ as appropriate at $37{ }^{\circ} \mathrm{C}$. When the culture had reached an optical density $\left(\mathrm{OD}_{600}\right)$ of 0.5 , isopropyl- $\beta$-D-thiogalactopyronoside (IPTG) at different concentrations was added to induce protein expression and then growth was continued for $4 \mathrm{~h}$. After IPTG induction, samples of the cells were harvested and analyzed for protein expression. Protein concentration was determined using the procedure described in a previous study [21]. Samples 
containing the various expressed proteins, His-TATApoptin or His-TAT-Apoptin ${ }_{\text {opt }}$ and GST-TAT-Apoptin or GST-TAT-Apoptin opt , were analyzed by $12.5 \%$ SDSPAGE and Western-blotting using a monoclonal antiHis antibody (Invitrogen, Carlsbad, CA) or a monoclonal anti-GST antibody (GE healthcare, Piscataway, NJ).

\section{Purification of recombinant GST-TAT-Apoptin ${ }_{\text {opt }}$ protein using GST affinity chromatography}

To purify the recombinant GST-TAT-Apoptin ${ }_{\text {opt }}$ proteins, cells were spun down from $50 \mathrm{~mL}$ of culture supernatant and resuspended in GST resin binding buffer $\left(140 \mathrm{mM} \mathrm{NaCl}, 2.7 \mathrm{mM} \mathrm{KCl}, 10 \mathrm{mM} \mathrm{Na} 2 \mathrm{HPO}_{4}\right.$, $1.8 \mathrm{mM} \mathrm{KH} \mathrm{PO}_{4}, \mathrm{pH}$ 7.3). The mixture was then sonicated on ice three times for 3 minutes with a $20 \%$ pulsed activity cycle (MISONIX Sonicator ${ }^{\circledR} 300$ ). Next, the lysate was centrifuged for $10 \mathrm{~min}$ at $10,000 \mathrm{rpm}$ to remove the cell debris. The resulting cell supernatant was loaded onto a GSTrap FF affinity column (GE healthcare, Piscataway, NJ) for protein purification using the standard procedure described in a previous study [21]. The total protein concentration of each collected fraction from the column was determined using a Micro BCA kit (Pierce, Rockford, IL) with bovine serum albumin acting as the reference protein. The purity of the protein from each fraction was analyzed by $12.5 \%$ SDS-PAGE and then the resulting gels were Western blotted using monoclonal anti-GST antibody (GE healthcare, Piscataway, NJ).

\section{Mass spectrometry}

To confirm the identity of the recombinant apoptin protein, E. coli expressed GST-TAT-Apoptin was purified by GSTrap FF column, and then the eluted proteins containing in collected fraction were separated by $12.5 \%$ SDS-PAGE. The relevant band was then cut out from the 12.5\% SDS-PAGE gel after Coomassie blue staining and digested with trypsin. The resulting samples were subjected to the MALDI-TOF-MS mass spectrometry (ESIQUAD-TOF) to allow amino acid sequence identification of the protein, as described in a previous study [17].

\section{Apoptosis assay}

Human promyelocytic leukemia HL-60 cells (CCRC 60043) were purchased from the Food Industry Research and Development Institute (FIRDI) (Hsichu. Taiwan). These cells were used to evaluate the apoptotic activity of GST-TAT-Apoptin ${ }_{\text {opt }}$ using an Annexin-V FITC apoptosis kit (BD Phaemingen, San Diego, CA). The cell was grown in the FIRDI-suggested medium, and all experiments were performed in 6-well culture plates. The cultured HL-60 cells were stained with Annexin-V FITC and propidium iodide (PI) according to manufacturer's guidelines. Briefly, $2 \times 10^{5}$ cells were co-cultured with 90 $\mathrm{ug} / \mathrm{ml}$ of GST-TAT-Apoptin ${ }_{\mathrm{opt}}$ for $24 \mathrm{hrs}$, and then resuspended in $100 \mathrm{ul}$ of $1 \times$ binding buffer, which was followed by incubation with $2.5 \mathrm{ul}$ of Annexin-V FITC and PI at room temperature for $30 \mathrm{~min}$. Finally the cells were added to $200 \mathrm{ul}$ of $1 \times$ binding buffer and assayed immediately using FACSCanto flow cytometry (BD Biosciences, San Jose, CA). A positive control was included and this consisted of treating the cells with $100 \mathrm{mM}$ cycloheximide (CHX) (Sigma-Aldrich, USA) for $24 \mathrm{hrs}$. The negative controls were either cells treated with protein buffer $(50 \mathrm{mM}$ Tris- $\mathrm{HCl}, 10 \mathrm{mM}$ reduced glutathione, $\mathrm{pH}$ 8.0) or cells treated with $90 \mathrm{ug} / \mathrm{ml}$ glutathione$\mathrm{S}$-transferase (GST) protein for $24 \mathrm{hrs}$.

\section{Competing interests}

All of authors declare no competing interests.

\section{Acknowledgments}

This work was supported by the grant from China Medical University of Taiwan (CMU100-TS-05) and the National Science Council (NSC 95-2313-B039-004-, NSC96-2313-B-276-001-MY3), Taiwan.

\section{Author details}

'School of Chinese Pharmaceutical Sciences and Chinese Medicine Resources, China Medical University, Taichung, 40402Taiwan, Republic of China. ${ }^{2}$ Department of Bioresources, Da-Yeh University, Changhua, 51591Taiwan, Republic of China. ${ }^{3}$ Graduate School of Biotechnology, Hung Kuang University, Taichung, 43302Taiwan, Republic of China. ${ }^{4}$ Department of Veterinary Medicine, National Pingtung University of Science and Technology, Pingtung, 91201Taiwan, Republic of China. ${ }^{5}$ Graduate Institute of Biotechnology, College of Agriculture and Natural Resources, National Chung Hsing University, Taichung, Taiwan. ${ }^{6}$ Department of Medical Research, Tung's Taichung MetroHarbor Hospital, Taichung, 43344Taiwan, Republic of China. Institute of Pharmacology, National Yang-Ming University, College of Medicine, Taipei, 11221Taiwan, Republic of China. ${ }^{8}$ Department of Safety, Health and Environmental Engineering, Mingchi University of Technology, Taipei, 24301Taiwan, Republic of China. ${ }^{9}$ Department of Nursing, Chung Jen College of Nursing, Health Sciences and Management, Chia-Yi, Taiwan.

\section{Authors' contributions}

MSL participated in this study design, performed the experiments and helped with the writing of the manuscript. SHF, GHL and FCS performed the experiments and participated in the construction of the plasmids. YYL participated in the experiments on protein antigenicity and $\mathrm{GHL}, \mathrm{CHH}$ and $J \mathrm{C}$ participated in the protein purification. $\mathrm{HJC}$ and $\mathrm{MSL}^{6}$ participated in the data analysis and the writing of the manuscript. MSL, HYC and JTCT coordinated the study and participated in the writing of the manuscript. All authors read and approved the final manuscript.

Received: 19 March 2012 Accepted: 6 June 2012 Published: 6 June 2012

\section{References}

1. Ducatez MF, Owoade AA, Abiola JO, Muller CP: Molecular epidemiology of chicken anemia virus in Nigeria. Arch Virol 2006, 151:97-111.

2. Meehan BM, Todd D, Creelan JL, Earle JA, Hoey EM, McNulty MS: Characterization of viral DNAs from cells infected with chicken anemia agent: sequence analysis of the cloned replicative form and transfection capabilities of cloned genome fragments. Arch Virol 1992, 124:301-319.

3. Noteborn MH, de Boer GF, van Roozelaar DJ, Karreman C, Kranenburg O, Vos JG, Eurissen SHJ, Hoeben RC, Zantema A, Koch G: Characterization of cloned chicken anemia virus DNA that contains all elements for the infectious replication cycle. J Virol 1991, 65:3131-3139.

4. Yuasa N, Imai K, Watanabe K, Saito F, Abe M, Komi K: Aetiological examination of an outbreak of haemorrhagic syndrome in a broiler flock in Japan. Avian Pathol 1987, 16:521-526. 
5. Peters MA, Jackson DC, Crabb BS, Browning GF: Chicken anemia virus VP2 is a novel dual specificity protein phosphatase. J Biol Chem 2002, 277:39566-39573.

6. Noteborn MH, Todd D, Verschueren CA, de Gauw HW, Curran WL, Veldkamp S, Douglas AJ, McNulty MS, van der Eb AJ, Koch G: A single chicken anemia virus protein induces apoptosis. J Virol 1994, 68:346-351.

7. Habib NA: Cancer gene therapy- past achievements and future challenges. New York: Kluwer Academic/ Plenum Publisher; 2000:155.

8. Mae M, Langel U: Cell-penetrating peptides as vectors for peptides, protein and oligonucleotide delivery. Curr Opin Pharmacol 2006, 6:509514.

9. Li $X$, Jin N, Mi Z, Lian H, Sun L, Zheng H: Antitumor effects of a recombinant fowlpox virus expressing Apoptin in vivo and in vitro. Int $J$ Cancer 2006, 119:2948-2957.

10. Pietersen AM, van der Eb MM, Rademaker HJ, van den Wollenberg DJ, Rabelink MJ, Kuppen PJ, van Dierendonck JH, Van Ormondt H, Masman D, van de Velde CJ, van der Eb AJ, Hoeben RC, Noteborn MH: Specific tumorcell killing with adenovirus vectors containing the apoptin gene. Gene Ther 1999, 6:882-892.

11. Los M, Panigrahi S, Rashedi I, Mandal S, Stetefeld J, Essmann F, SchulzeOsthoff K: Apoptin, a tumor-selective killer. Biochim Biophys Acta 2009, 1793:1335-1342.

12. Green M, Loews, Enstein PM: Autonomous functional domain of chemically synthesized human immunodeficiency virus tat transactivator protein. Cell 1988, 55:1179-1188.

13. Guelen L, Paterson H, Gäken J, Meyers M, Farzaneh F, Tavassoli M: TATapoptin is efficiently delivered and induces apoptosis in cancer cells. Oncogene 2004, 23:1153-1165.

14. Han SX, Ma JL, LV Y, Huang C, Liang HH, Duan KM: Secretory Transactivating Transcription-apoptin fusion protein induces apoptosis in hepatocellular carcinoma HepG2 cells. World J Gastroenterol 2008, 14:3642-3649.

15. Iwata N, Fujino M, Tuchiya K, Iwata A, Otaki Y, Ueda S: Development of an enzyme-linked immunosorbent assay using recombinant chicken anemia virus proteins expressed in a baculovirus vector system. J Vet Med Sci 1998, 60:175-180.

16. Lacorte $\mathrm{C}$, Lohuis $\mathrm{H}$, Goldbach $\mathrm{R}$, Prins M: Assessing the expression of chicken anemia virus proteins in plants. Virus Res 2007, 129:80-86.

17. Lee MS, Chou YM, Lien YY, Lin MK, Chang WT, Lee HZ, Lee MS, Lai GH, Chen $\mathrm{HJ}$, Haung $\mathrm{CH}$, Lin WH: Production and diagnostic application of a purified, E. coli-expressed, serological specific chicken anemia virus antigen VP3. Transbound Emerg Dis 2011, 58:232-239.

18. Nogueira-Dantas EO, Ferreira AJ, Astolfi-Ferreira CS, Brentano L: Cloning and expression of chicken anemia virus VP3 protein in Escherichia coli. Comp Immunol Microbial Infect Dis 2007, 30:133-142.

19. Flinterman M, Farzaneh F, Habib N, Malik F, Gäken J, Tavassoli M: Delivery of therapeutic proteins as secretable TAT fusion products. Mol Ther 2009, 17:334-342

20. Makrides SC: Strategies for achieving high-level expression of genes in Escherichia coli. Microbiol Rev 1996, 60:512-538.

21. Lee MS, Hseu YC, Lai GH, Chang WT, Chen HJ, Huang CH, Lee MS, Wang MY, Kao JY, You BJ, Lin W, Lien YY, Lin MK: High yield expression in a recombinant $E$. coli of a codon optimized chicken anemia virus capsid protein VP1 useful for vaccine development. Microb Cell Fact 2011, 10:56.

22. Trundova M, Celer V: Expression of porcine circovirus 2 ORF2 gene requires codon optimized E. coli cells. Virus Genes 2007, 34:199-204.

23. Liu Q, Willson P, Attoh-Poku S, Babiuk LA: Bacterial expression of an immunologically reactive PCV2 ORF2 fusion protein. Protein Expr Purif 2001, 21:115-120.

24. Sun SQ, Guo HC, Sun DH, Yin SH, Shang YJ, Cai XP, Liu XT: Development and validation of an ELISA using a protein encoded by ORF2 antigenic domain of porcine circovirus type 2. Virol J 2010, 7:274-280.

25. Kurland $\mathrm{CG}$, Dong $\mathrm{H}$ : Bacterial growth inhibition by overproduction of protein. Mol Microbiol 1996, 21:1-4.

26. Rosenberg AH, Goldman E, Dunn JJ, Studier FW, Zubay G: Effects of consecutive AGG codons on translation in Escherichia coli, demonstrated with a versatile codon test system. J Bacteriol 1993, 175:716-722.

27. Rosano GL, Ceccarelli EA: Rare codon content affects the solubility of recombinant proteins in a codon bias-adjusted Escherichia coli strain. Microb Cell Fact 2009, 8:41-49.
28. Gvritishvili AG, Leung KW, Tombran-Tink J: Codon preference optimization increases heterologous PEDF expression. PLoS One 2010, 5:e15056.

doi:10.1186/1472-6750-12-27

Cite this article as: Lee et al:: Efficient Production of an Engineered Apoptin from Chicken Anemia Virus in a Recombinant E. coli for Tumor Therapeutic Applications. BMC Biotechnology 2012 12:27.

\section{Submit your next manuscript to BioMed Central and take full advantage of:}

- Convenient online submission

- Thorough peer review

- No space constraints or color figure charges

- Immediate publication on acceptance

- Inclusion in PubMed, CAS, Scopus and Google Scholar

- Research which is freely available for redistribution 